\title{
Assimilation and regeneration of inorganic nitrogen in a coastal upwelling system: ammonium and nitrate utilization
}

\author{
C. Fernandez ${ }^{1,2, *}$, L. Farías ${ }^{2,3}$ \\ ${ }^{1}$ UPMC Univ Paris 06 and CNRS, UMR 7621, LOMIC, Observatoire Océanologique, 66651, Banyuls/mer, France \\ ${ }^{2}$ Departamento de Oceanografía, Centro de Investigación Oceanográfica en el Pacífico Sudoriental (COPAS), \\ Universidad de Concepción, Concepción, Chile \\ ${ }^{3}$ Laboratorio de Procesos Oceanográficos y Clima, Universidad de Concepción, Casilla 160-C, Concepción, Chile
}

ABSTRACT: The main processes involved in nitrogen cycling (as $\mathrm{NO}_{3}{ }^{-}$and $\mathrm{NH}_{4}{ }^{+}$assimilation and their regeneration) were studied using $\mathrm{N}$-tracer experiments in the coastal upwelling system off central Chile $\left(36^{\circ} \mathrm{S}\right)$. The study area shows seasonal surface fertilization and the development of subsurface hypoxia in austral spring and summer. The rates of $\mathrm{NO}_{3}{ }^{-}$uptake during active upwelling were 5 times higher than in non-upwelling seasons. Uptake of $\mathrm{NH}_{4}{ }^{+}$was almost half that of $\mathrm{NO}_{3}{ }^{-}$uptake rates during upwelling periods, and similar to $\mathrm{NO}_{3}{ }^{-}$uptake rates in the absence of upwelling. Nitrification experiments showed higher rates during active, compared to non-active, upwelling seasons. $\mathrm{NH}_{4}{ }^{+}$oxidation was coupled with $\mathrm{NO}_{2}{ }^{-}$oxidation in near bottom (suboxic) waters, while in the oxycline (hypoxic water), total fluxes of $\mathrm{NO}_{3}{ }^{-}$regeneration via nitrification resulted from higher activity of $\mathrm{NO}_{2}{ }^{-}$oxidation compared to $\mathrm{NH}_{4}{ }^{+}$oxidation. On the other hand, archaeal $\mathrm{NH}_{4}{ }^{+}$oxidation had the potential for processing a large fraction of $\mathrm{NH}_{4}{ }^{+}$and could therefore co-occur with bacterial $\mathrm{NO}_{2}^{-}$oxidation. $\mathrm{NH}_{4}{ }^{+}$utilization in this coastal upwelling is thus in the same range as $\mathrm{NO}_{3}{ }^{-}$assimilation. $\mathrm{NH}_{4}{ }^{+}$oxidation is affected by oxygen concentration in the water column, leading to occasional decoupling of $\mathrm{NH}_{4}{ }^{+}$and $\mathrm{NO}_{2}{ }^{-}$ oxidation, particularly at the oxycline. This study gives preliminary evidence of the importance of archaealbacterial interactions in the nitrification process and highlights the role of ammonium in fueling annual primary production in coastal upwelling systems.

KEY WORDS: Coastal upwelling $\cdot$ Nitrogen uptake · Ammonium oxidation $\cdot$ Archaea

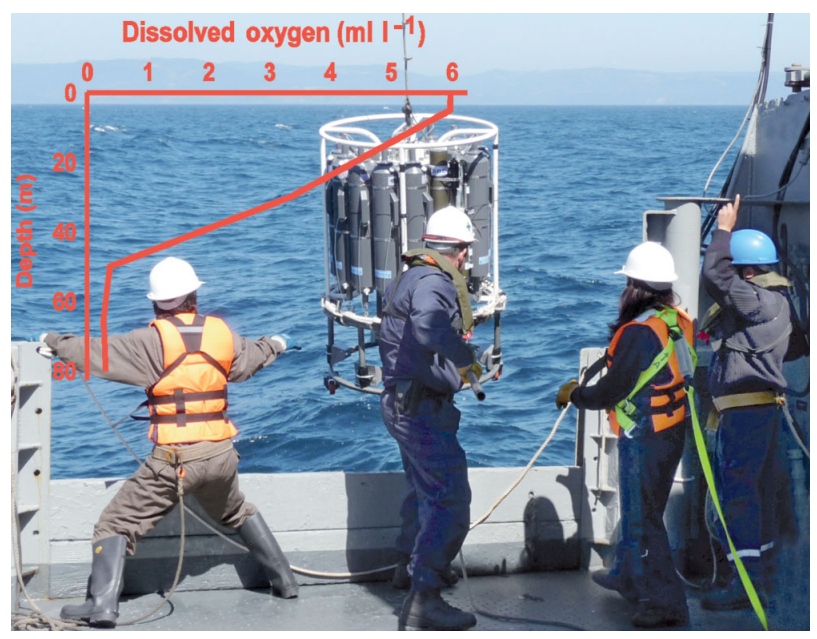

Oxygen concentrations decrease rapidly in the water column off central Chile, and this modulates the activity of microbial communities involved in the nitrogen cycle.

Photo: C. Fernandez

\section{INTRODUCTION}

Research on nitrogen $(\mathrm{N})$ cycling in marine ecosystems has been largely influenced by the conceptual partitioning between new and regenerated production, in which primary production supported by new $\mathrm{N}$ should be quantitatively equal to the organic material exported below the surface ocean (Dugdale \& Goering 1967, Eppley \& Peterson 1979).

New $\mathrm{N}$ is mainly represented by nitrate $\left(\mathrm{NO}_{3}{ }^{-}\right)$, which is injected into the euphotic zone by mixing and vertical advection (upwelling), whereas ammo- 
nium $\left(\mathrm{NH}_{4}{ }^{+}\right)$, the most common form of 'regenerated' $\mathrm{N}$, is mainly released during bacterial remineralization of dissolved organic matter (DOM) in the water column (Bronk 2002, Mopper \& Kieber 2002) as well as by zooplankton excretion (Alcaraz et al. 1994).

$\mathrm{NO}_{3}{ }^{-}$regeneration was not included in this balance and considered for long time as negligible for $\mathrm{N}$ fluxes in surface waters (Dugdale \& Goering 1967). However, it is now widely recognized that nitrification plays an important role in surface $\mathrm{N}$ budgets through the stepwise oxidation of $\mathrm{NH}_{4}{ }^{+}$into nitrite $\left(\mathrm{NO}_{2}^{-}\right.$) and $\mathrm{NO}_{3}^{-}$(Yool et al. 2007).

The production of $\mathrm{NO}_{3}^{-}$via nitrification results from a coupling between $\mathrm{NH}_{4}{ }^{+}$and $\mathrm{NO}_{2}{ }^{-}$oxidizers in the marine environment, but the variability of this biogeochemical coupling is not fully understood. Both groups use oxygen as an electron acceptor and inorganic carbon as a carbon source and obtain their reducing power from $\mathrm{NH}_{4}{ }^{+}$and $\mathrm{NO}_{2}{ }^{-}$, respectively.

Aerobic $\mathrm{NH}_{4}{ }^{+}$oxidation includes $\mathrm{NH}_{4}{ }^{+}$oxidizing bacteria (AOB) as well as $\mathrm{NH}_{4}^{+}$oxidizing Crenarchaeota (AOA; Könneke et al. 2005), while the oxidation of $\mathrm{NO}_{2}^{-}$is performed only by nitrite oxidizing bacteria (NOB). Niche partitioning among nitrifying communities is beginning to be studied in detail; it is likely to be determined by the physiological characteristics of the community as a function of substrate and oxygen concentration. AOA possess a lower halfsaturation constant and substrate threshold compared to bacteria, which indicates an enhanced capacity to adapt to oligotrophic conditions. This would confer to archaea a competition advantage against heterotrophic bacteria and phytoplankton in open ocean systems (Martens-Habbena et al. 2009). Also, AOA are particularly active in oxygen-deficient nutrientrich waters and can be more abundant than AOB in coastal upwelling systems (Molina et al. 2010).

Nitrification could therefore play an important biogeochemical role in the ocean, not only as a remineralization process but also by supplying inorganic nutrients for photosynthesis and electron acceptors for $\mathrm{NO}_{3}{ }^{-}$reduction-denitrification in suboxic and hypoxic conditions such as those found in upwelling systems and Oxygen Minimum Zones (OMZ).

The coastal upwelling system off central Chile $\left(36^{\circ} \mathrm{S}\right)$ shows significant rates of primary and secondary production (Daneri et al. 2000, Montero et al. 2007). Active upwelling occurs in austral spring and summer, when intensification of the south and southwest winds drives the upwelling of Equatorial Subsurface Water (ESSW) with high $\mathrm{NO}_{3}^{-}$and low $\mathrm{O}_{2}$ concentrations (Sobarzo \& Djurfeldt 2004). During late autumn and winter, non-active upwelling condi- tions are observed, when northerly winds intensely mix Sub-Antarctic Water (SAAW), rich in dissolved $\mathrm{O}_{2}$, causing biological production to slow down. The water column in this area presents distinct chemical gradients, which are separated by the oxycline into at least 2 layers: an oxygenated and illuminated layer, and an oxygen-limited, non-illuminated subsurface water where important accumulations of $\mathrm{NH}_{4}{ }^{+}, \mathrm{NO}_{2}{ }^{-}$, and $\mathrm{N}_{2} \mathrm{O}$ (nitrous oxide) may result from the coupling of chemo- and heterotrophic processes. The water column also shows gradients in the richness of $\mathrm{AOB}$ and AOA populations, indicating the presence of differentiation niches along the oxygen and nutrient gradients. Recent observations also suggest that chemosynthetic processes such as nitrification and methane oxidation contribute significantly to of the carbon fixation and affect the cycling of nutrients throughout the water column (Farías et al. 2009b).

The objective of this study was to estimate autotrophic $\mathrm{NO}_{3}^{-}$and $\mathrm{NH}_{4}^{+}$uptake in the coastal upwelling area of central Chile, taking the entire microbial community into consideration. We also studied the biogeochemical interaction between $\mathrm{N}$ uptake and regeneration, with special emphasis on the coupling within the nitrifying community (including AOA, AOB, and NOB). We report seasonal survey data and process-targeted experiments carried out during the spring-summer upwelling season.

\section{MATERIALS AND METHODS}

\section{Study area and sampling strategy}

Sampling was carried out monthly at the COPAS time series Stn 18 (36 30.8' S, 7307.75' W) on board the RV 'Kay-Kay II' of the Universidad de Concepción. This observation site (92 m bottom depth, Fig. 1) was visited between December 2006 and May 2008. Hydrographic data (temperature, salinity, $\mathrm{O}_{2}$, fluorescence) were obtained using a CTD (Seabird 25) with an $\mathrm{O}_{2}$ probe and fluorescence and photosynthetically active radiation (PAR) sensors (e.g. optical sensor Satlantic for PAR) attached to a rosette. The depth of the euphotic zone was considered as the depth down to which irradiation is equivalent to $1 \%$ of its surface value based on the attenuation coefficient of downwelling scalar irradiance in the PAR region (400-700 $\mathrm{nm}$ waveband).

Dissolved oxygen concentrations were determined through the Winkler method using a semi-automatic system (AULOX) developed at the University of Concepción (LabPROFC). Samples for nutrient determi- 


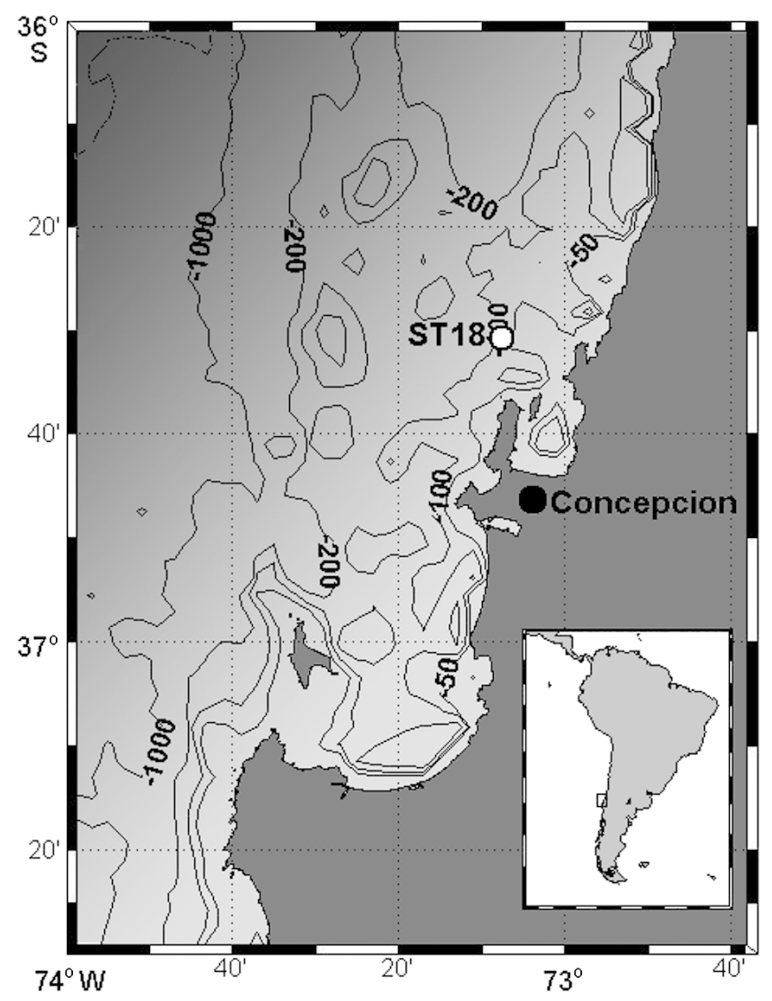

Fig. 1. Study area in the coastal upwelling system off central Chile

nation were taken and frozen in duplicate for laboratory analysis. Seawater samples were filtered $(0.7 \mu \mathrm{m}$, $\mathrm{GF} / \mathrm{F}$ ) on board and stored frozen until analysis. Concentrations of dissolved $\mathrm{NO}_{2}{ }^{-}, \mathrm{NO}_{3}{ }^{-}$, and $\mathrm{PO}_{4}{ }^{3-}$ (phosphate) were determined using standard manual colorimetric techniques following Grasshoff et al. (1983). For $\mathrm{NH}_{4}^{+}$concentrations, samples (in triplicate) were taken directly from the Niskin bottle in $50 \mathrm{ml}$ Pyrex (Duran Schott) flasks. Each sample $(40 \mathrm{ml})$ received $10 \mathrm{ml}$ of working solution. Samples were then stored in the dark for $2 \mathrm{~h}$ and analyzed by the fluorometric method (Holmes et al. 1999) using a Turner design ${ }^{\circledR}$ fluorometer. The precision of $\mathrm{NO}_{3}{ }^{-}$, $\mathrm{NO}_{2}{ }^{-}$, and $\mathrm{NH}_{4}{ }^{+}$in terms of the $\mathrm{CV}$ was better than $\pm 10, \pm 3$, and $\pm 5 \%$, respectively.
In addition to the time series program sampling, a process-oriented cruise was performed in January 2008 during the NICCHEX I cruise (RV 'Kay Kay II') during active upwelling conditions. During this cruise (immediately after the monthly sampling of Stn 18 by the COPAS program), water samples were taken from 2 depth levels: $30 \mathrm{~m}$, which corresponds to the oxycline, and $80 \mathrm{~m}$, which corresponds to nearbottom waters (free from the effect of particulate organic matter re-suspension as well as $\mathrm{NH}_{4}{ }^{+}$efflux from the sediments; Farías et al. 2004). The samples were used for biogeochemical incubations using ${ }^{15} \mathrm{~N}$ tracers and specific inhibitors as outlined in Table 1.

\section{${ }^{15} \mathrm{~N}$ uptake and regeneration experiments}

Incubation experiments were performed monthly using an in situ mooring line at Stn 18. Samples were taken in acid-cleaned polycarbonate bottles (600 ml) at 5 depth levels $(5,15,30,50$, and $80 \mathrm{~m})$. Samples were amended with ${ }^{15} \mathrm{~N}$-labeled substrate and incubated in situ for 8 to $12 \mathrm{~h}$ (dawn to dusk). Incubations were terminated by gentle vacuum filtration ( $<100 \mathrm{~mm} \mathrm{Hg}$ ) through pre-combusted GF/F filters $\left(450^{\circ} \mathrm{C}\right.$ for $\left.12 \mathrm{~h}\right)$. Filters were then dried at $60^{\circ} \mathrm{C}$ for $24 \mathrm{~h}$ and stored at constant temperature until laboratory analysis by continuous-flow isotope ratio mass spectrometry (IRMS; Finnigan Delta Plus).

${ }^{15} \mathrm{~N}$ tracer additions were performed as ${ }^{15} \mathrm{NH}_{4} \mathrm{Cl}$ $\left(99 \%\right.$ at $\left.0.5 \mu \mathrm{mol} \mathrm{ml} \mathrm{m}^{-1}\right)$ or $\mathrm{K}^{15} \mathrm{NO}_{3}(99 \%$ at $0.5 \mu \mathrm{mol}$ $\mathrm{ml}^{-1}$ ). Samples taken for nutrient ambient concentrations were analyzed after the in situ experiments. The 10 yr old time series Stn 18 (COPAS) data set available allowed us to estimate the necessary tracer addition. Final tracer concentrations were variable but often close to $10 \%$ of ambient concentration. At low initial $\mathrm{NH}_{4}{ }^{+}$concentrations $(<50 \mathrm{nmol}$ $\left.\mathrm{l}^{-1}\right)$, minimum tracer additions as ${ }^{15} \mathrm{NH}_{4} \mathrm{Cl}(99 \%$ at $0.5 \mu \mathrm{mol} \mathrm{ml} \mathrm{m}^{-1}$ ) resulted in initial enrichments $\left(T_{0}\right)$ exceeding $50 \%$. In such cases, rates should be considered as potential uptake. It is important to note,

Table 1. Experimental setup for targeted experiments carried out during the NICCHEX I cruise at 30 and $80 \mathrm{~m}$ depth. $\mathrm{NH}_{4} \mathrm{Ox}$ : ammonium oxidation; $\mathrm{NO}_{2} \mathrm{ox}$ : nitrite oxidation; denitrific.: denitrification

\begin{tabular}{|lllll|}
\hline Targeted process & Treatment & Inhibitor & Expected result & Source \\
\hline Nitrite oxidation & ${ }^{15} \mathrm{NO}_{2}$ & Allylthiourea (ATU) & Inhibition of $\mathrm{NH}_{4} \mathrm{Ox}$ & Ginestet et al. (1998) \\
Ammonium oxidation & ${ }^{15} \mathrm{NH}_{4}$ & Sodium azide (NaN $\left.\mathrm{N}_{3}\right)$ & Inhibition of $\mathrm{NO}_{2} \mathrm{Ox}$ and denitrific. & Ginestet et al. (1998) \\
Bacterial ammonium oxidation & ${ }^{15} \mathrm{NH}_{4}$ & GC7 & Inhibition of archaeal biosynthesis & Jansson et al. (2000) \\
Net ammonium oxidation & ${ }^{15} \mathrm{NH}_{4}$ & No inhibitor & Net nitrification control & Slawyk \& Raimbault (1995) \\
Control & ${ }^{15} \mathrm{NH}_{4}$ & $\mathrm{HgCl}_{2}$ & Negative control & \\
\hline
\end{tabular}


however, that ambient $\mathrm{NH}_{4}{ }^{+}$concentrations were generally above the detection limit and could often exceed $0.5 \mu \mathrm{mol} \mathrm{l} \mathrm{l}^{-1}$. In contrast, high $\mathrm{NO}_{3}{ }^{-}$concentrations allowed keeping ${ }^{15} \mathrm{~N}$ tracer additions as $\mathrm{K}^{15} \mathrm{NO}_{3}\left(99 \%\right.$ at $\left.0.5 \mu \mathrm{mol} \mathrm{ml}{ }^{-1}\right)$ close to $10 \%$ of ambient values. Subsamples were taken directly from the incubation bottle before filtration and analyzed for determination of final $\mathrm{NO}_{3}{ }^{-}$and $\mathrm{NH}_{4}{ }^{+}$ concentrations.

The transport rate of ${ }^{15} \mathrm{~N}$-labeled dissolved inorganic N (DIN) to the particulate organic N (PON) pool, i.e. the net DIN uptake ( $\rho$ DIN, $n m o l l^{-1} \mathrm{~d}^{-1}$ ) was computed according to Eq. 1:

$$
\rho \mathrm{DIN}=\frac{R_{\mathrm{PON}}}{R_{\mathrm{DIN}} \times T} \times[\mathrm{PON}]
$$

where $R_{\mathrm{PON}}$ and $R_{\mathrm{DIN}}$ represent the ${ }^{15} \mathrm{~N}$ atom percent excess enrichment in the PON and DIN pools, and $[\mathrm{PON}]$ represents the final PON concentration; $T$ represents the duration $(\mathrm{h})$ of the incubation. The measurement of isotopic enrichment in the DIN pool provides a check on the isotope dilution of the ${ }^{15} \mathrm{~N}$ tracer due to DIN regeneration and thus corrects for underestimation of DIN uptake rates. To correct $\mathrm{NH}_{4}{ }^{+}$uptake rates for isotopic dilution (caused by in situ regeneration of organic matter during incubation), we made $R_{\text {DIN }}$ in Eq. (1) equal to the mean value between initial and final enrichment value $\left(R_{\mathrm{NH}_{4}}\right)$. Uptake rates are expressed as daily rates, taking the standard length of a solar day (12 h) into account (hourly rate $\times 12$ ).

$\mathrm{NH}_{4}{ }^{+}$regeneration $\left(\mathrm{rNH}_{4}\right)$ and net nitrification $\left(\mathrm{rNO}_{3}\right)$ were measured for all ${ }^{15} \mathrm{NH}_{4}$ incubations by a triple diffusion isotopic method (Slawyk \& Raimbault 1995, Raimbault et al. 1999). After ending the ${ }^{15} \mathrm{NH}_{4}$ incubations, $300 \mathrm{ml}$ filtrates were recovered in Duran Schott flasks and amended with $1 \mathrm{ml} \mathrm{HgCl}_{2}\left(6 \mathrm{~g} \mathrm{l}^{-1}\right)$. This procedure does not affect the extraction efficiency and prevents losses of $\mathrm{NH}_{4}{ }^{+}$by freezing the sample. Filtrates of ${ }^{15} \mathrm{NH}_{4}$ incubations were used to measure the final ${ }^{15} \mathrm{~N}$ enrichment in the DIN pool, as outlined by Slawyk \& Raimbault (1995). By removing all forms of DIN from the sample as $\left(\mathrm{NH}_{4}\right)_{2} \mathrm{SO}_{4}$, this procedure allows estimating sequentially the final ${ }^{15} \mathrm{~N}$ enrichment of the DIN pool (DIN ${ }^{15} \mathrm{~N}$ ) and the isotope dilution of the tracer due to $\mathrm{NH}_{4}{ }^{+}$regeneration, then to estimate net nitrification via $\mathrm{NH}_{4}{ }^{+}$oxidation to $\mathrm{NO}_{2}{ }^{-}+\mathrm{NO}_{3}{ }^{-}$and finally the loss of tracer as DON during the incubation process. Filters recovered after each step were dried at $60^{\circ} \mathrm{C}$ and analyzed by IRMS. The same procedure was applied to samples amended with allylthiourea (ATU) at a final concentration of $86 \mu \mathrm{mol} \mathrm{l^{-1 }}$ (Ginestet et al. 1998).
ATU inhibits $\mathrm{NH}_{4}{ }^{+}$oxidation in AOB. However, it has not been well studied in AOA. Therefore, if AOB (and perhaps also AOA) are active in a water sample, samples amended with ATU are expected to accumulate ${ }^{15} \mathrm{NH}_{4}{ }^{+}$during incubation in the absence of $\mathrm{NH}_{4}{ }^{+}$oxidation.

Net nitrification rates $\left(\mathrm{rNO}_{3}, \mu \mathrm{mol} \mathrm{l} \mathrm{l}^{-1} \mathrm{~d}^{-1}\right)$ were computed according to Eq. (2):

$$
\mathrm{rNO}_{3}=\left(\frac{R_{\mathrm{NO}_{3}}}{R_{\mathrm{NH}_{4}} \times T}\right) \times\left[\mathrm{NO}_{3}\right]
$$

where $R_{\mathrm{NO}_{3}}$ is the ${ }^{15} \mathrm{~N}$ atom percent excess enrichment in the $\left(\mathrm{NO}_{3}{ }^{-}+\mathrm{NO}_{2}{ }^{-}\right)$pool, $R_{\mathrm{NH}_{4}}$ is the mean ${ }^{15} \mathrm{~N}$ atom percent excess enrichment of the $\mathrm{NH}_{4}{ }^{+}$pool, and $\left[\mathrm{NO}_{3}\right]$ is the final $\mathrm{NO}_{3}{ }^{-}$concentration in the sam-

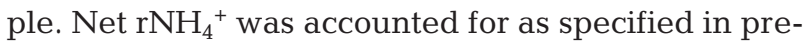
vious surveys in the area (Raimbault \& Garcia 2008) and according to Eq. (3):

$$
\mathrm{rNH}_{4}=\frac{\left[\mathrm{NH}_{4}\right]_{0}+\left[\mathrm{NH}_{4}\right]_{\mathrm{F}}}{2 T} \times \ln \left(\frac{R_{0\left(\mathrm{NH}_{4}\right)}}{R_{\mathrm{F}\left(\mathrm{NH}_{4}\right)}}\right)
$$

where $\left[\mathrm{NH}_{4}\right]_{0}$ and $\left[\mathrm{NH}_{4}\right]_{\mathrm{F}}$ represent the initial and final concentrations of $\mathrm{NH}_{4}{ }^{+}$during the incubation experiment, respectively. The terms $R_{0\left(\mathrm{NH}_{4}\right)}$ and $R_{\mathrm{F}\left(\mathrm{NH}_{4}\right)}$ represent the initial and final excess enrichments in ${ }^{15} \mathrm{NH}_{4}{ }^{+}$during the incubation period.

\section{Aerobic $\mathrm{NH}_{4}{ }^{+}$oxidation experiments}

The vertical structure of the water column in the study area adds methodological complexities to our experimental setup, since some coupling between oxidative and reductive processes can occur under low oxygen conditions (i.e. $\mathrm{NH}_{4}{ }^{+}$and $\mathrm{NO}_{2}{ }^{-}$oxidation with $\mathrm{NO}_{3}{ }^{-}$and $\mathrm{NO}_{2}{ }^{-}$reduction). To assess such difficulties, a series of experiments with amended substrates and specific inhibitors was carried out during the NICCHEX I cruise (Nitrogen and Carbon Chemosynthetic Experiment, January 2008, active upwelling season).

Incubations were planned with samples retrieved at 2 depth levels, $30 \mathrm{~m}$ (oxycline) and $80 \mathrm{~m}$ (nearbottom water). These depth levels are representative of hypoxic $\left(\mathrm{O}_{2}<2 \mathrm{ml} \mathrm{l}^{-1}\right)$ and suboxic $\left(\mathrm{O}_{2}<0.2 \mathrm{ml} \mathrm{l}^{-1}\right)$ conditions within the aphotic layer (according to PAR profiles). For that reason, all incubations were performed in duplicate for periods of $12 \mathrm{~h}$ (which included $T_{0}, T_{0}+6 \mathrm{~h}$, and $T_{0}+12 \mathrm{~h}$ ) and in dark and in situ-simulated temperature conditions (using a Velp ${ }^{\circledR}$ incubator). Changes in $\mathrm{NH}_{4}{ }^{+}$and $\mathrm{NO}_{2}{ }^{-}+\mathrm{NO}_{3}{ }^{-}$ concentrations during the incubation were followed in the same experiment in order to estimate the net 
consumption of $\mathrm{NH}_{4}{ }^{+}$and production of $\mathrm{NO}_{2}{ }^{-}$with time.

The targeted processes for these experiments are listed in Table 1. Net nitrification (or $\mathrm{rNO}_{3}$ rate, performed by the total microbial community, which may include bacteria and archaea) was evaluated with ${ }^{15} \mathrm{NH}_{4}$ amendment as described in the previous section. On the other hand, gross and net $\mathrm{NH}_{4}{ }^{+}$and $\mathrm{NO}_{2}{ }^{-}$ oxidation were also evaluated separately (hereafter referred as $\mathrm{NH}_{4} \mathrm{OX}$ and $\mathrm{NO}_{2} \mathrm{OX}$, respectively). To this end, samples were amended with ${ }^{15} \mathrm{NH}_{4}$ or ${ }^{15} \mathrm{NO}_{2}$ in order to recover ${ }^{15} \mathrm{NO}_{2}+{ }^{15} \mathrm{NO}_{3}$ (via diffusion as described in the previous section). In addition, blockage of $\mathrm{NH}_{4} \mathrm{Ox}$ (as a control) was obtained in samples amended with ${ }^{15} \mathrm{NH}_{4}$ and ATU (see previous section). A further treatment was designed in order to evaluate bacterial nitrification in ${ }^{15} \mathrm{NH}_{4}$-amended samples, using an archaeal inhibitor (N1-guanyl-1,7-diaminoheptane, GC7) previously used in the study area (Levipan et al. 2007), which acts by arresting biosynthesis (Jansson et al. 2000). Samples amended with ${ }^{15} \mathrm{NH}_{4}$ were also treated with sodium azide $\left(\mathrm{NaN}_{3}\right)$ at a final concentration of $24 \mu \mathrm{mol} \mathrm{l}^{-1}$ (Ginestet et al. 1998) in order to block $\mathrm{NO}_{2}{ }^{-}$oxidation and disassimilative $\mathrm{NO}_{3}{ }^{-}$reduction, which should lead to an accumulation of $\mathrm{NO}_{2}{ }^{-}$while oxidation of $\mathrm{NH}_{4}{ }^{+}$proceeds (also reflected by high ${ }^{15} \mathrm{NO}_{2}+{ }^{15} \mathrm{NO}_{3}$ recovery). This approach was used to estimate $\mathrm{NH}_{4} \mathrm{Ox}$. In all cases, separate rates of $\mathrm{NH}_{4}{ }^{+}$and $\mathrm{NO}_{2}{ }^{-}$oxidation obtained by diffusion and rates obtained by nutrient evolution represent the difference between net rates of nitrification and rates obtained in inhibitor-amended samples. We acknowledge that the effect of each inhibition treatment cannot be warranted at $100 \%$ efficiency. Therefore, in some cases, rates of $\mathrm{NH}_{4}^{+}$or $\mathrm{NO}_{2}^{-}$oxidation may proceed to some extent after inhibitor addition. As additional controls, amended and un-amended samples were systematically tested after the addition of ${ }^{15} \mathrm{~N}$-tracers, using $\mathrm{HgCl}_{2}$.

Separated $\mathrm{NH}_{4}{ }^{+}$and $\mathrm{NO}_{2}{ }^{-}$oxidation rates were estimated by the difference between the rates obtained from ATU-amended treatments and the net nitrification rate (Molina \& Farias 2009):

$$
\mathrm{NH}_{4} \mathrm{Ox}=\mathrm{rNO}_{3}-\text { Control }-\mathrm{NH}_{4} \mathrm{ox}+\mathrm{ATU}
$$

$\mathrm{NO}_{2} \mathrm{Ox}$ rates were estimated by the difference between net nitrification rates and rates in inhibitoramended samples:

$$
\mathrm{NO}_{2} \mathrm{Ox}=\mathrm{rNO}_{3}-\text { Control }-\mathrm{NH}_{4} \mathrm{Ox}+\text { azide }
$$

Potential $\mathrm{NH}_{4}$ ox rates by archaea were obtained by the difference between net nitrification and rates obtained from GC7-amended samples.
Because of the large number of incubated bottles and samples generated, this experiment was not replicated on a monthly basis, as was the case for our time series uptake and regeneration experiments (see previous section).

\section{RESULTS}

\section{Seasonal oceanographic conditions}

The variability of temperature, oxygen, and nutrients at the study area is shown in Figs. 2 \& 3. During spring and summer (December 2006 to February 2007; September 2007 to February 2008), sea surface temperature (SST) oscillated between 13 and $14^{\circ} \mathrm{C}$, and maintained those values down to $20 \mathrm{~m}$ depth, where the thermocline was located. Temperatures reached $11^{\circ} \mathrm{C}$ in near-bottom waters. The winter temperature distribution (May to July 2007) showed homogeneous values around 11 to $12^{\circ} \mathrm{C}$ throughout the water column.

Dissolved oxygen concentrations in the water column also varied seasonally (Fig. 2b). Maximum oxygen levels were observed in surface waters in winter time $\left(>5 \mathrm{ml} \mathrm{l}^{-1}\right)$ and decreased to surface values $<3 \mathrm{ml} \mathrm{l}^{-1}$ in spring and summer. During austral spring and summer, oxygen concentrations can be lower than $0.1 \mathrm{ml} \mathrm{l}^{-1}$ in near-bottom waters. The depth of the oxycline varied between 20 and $30 \mathrm{~m}$ depth in summer and winter, respectively.

$\mathrm{NO}_{3}{ }^{-}$concentrations were always above detection limits (Fig. 3a). Surface concentrations during spring and summer were $<5 \mu \mathrm{mol} \mathrm{l}^{-1}$ but increased to $>30 \mu \mathrm{mol} \mathrm{l}^{-1}$ through the oxycline and near-bottom waters. Concentrations during winter showed values between 20 and $25 \mu \mathrm{mol} \mathrm{l^{-1 }}$ throughout the entire water column.

$\mathrm{NH}_{4}{ }^{+}$concentrations were generally high within the euphotic zone (Fig. 3b); maximum values were observed in spring and summer. The highest values were observed in summer 2007 (maximum $2 \mu \mathrm{mol} \mathrm{l}^{-1}$ at $20 \mathrm{~m}$ ) and 2008 (maximum $3.5 \mu \mathrm{mol} \mathrm{l}^{-1}$ in surface waters). Near the bottom, concentrations did not exceed $0.5 \mu \mathrm{mol} \mathrm{l}^{-1}$.

The N:P ratio (the ratio between total inorganic $\mathrm{N}$ and $\mathrm{PO}_{4}{ }^{3-}$ ) varied between 15:1 and 12:1 (Fig. 3c) throughout the water column from December 2006 to May 2007. However, from August 2007 to February 2008 , values in the water column were lower than the Redfield ratio of 16:1 (N:P $\sim 10)$. Values close to 15 were only observed occasionally in the upper oxycline (Fig. 2b). 


\section{Seasonal nitrogen uptake and regeneration}

$\mathrm{NO}_{3}{ }^{-}$uptake rates (expressed as $\mathrm{\rho NO}_{3}$ ) showed a seasonal trend with maximum values (average $1500 \pm 2000 \mathrm{nmol} \mathrm{l}^{-1} \mathrm{~d}^{-1}$ ) in spring and summer and minimum values in autumn and winter (average $100 \pm$ $100 \mathrm{nmol} \mathrm{l}^{-1} \mathrm{~d}^{-1}$; Fig. 4a). As a general trend, $\mathrm{NO}_{3}{ }^{-}$uptake was mainly concentrated in the first 20 to $30 \mathrm{~m}$ of the water column, being nearly an order of magnitude higher than rates obtained in subsurface layers.

$\mathrm{NH}_{4}{ }^{+}$uptake rates $\left(\rho \mathrm{NH}_{4}\right.$, Fig. $\left.4 \mathrm{~b}\right)$ throughout the water column showed lower values than $\mathrm{\rho NO}_{3}$ and were also concentrated in the first $30 \mathrm{~m}$ of the water column. The seasonal trend for $\mathrm{\rho NH}_{4}$ showed higher values during the spring-summer season (average $226 \pm 400 \mathrm{nmol} \mathrm{l}^{-1} \mathrm{~d}^{-1}$, maximum $1800 \mathrm{nmol} \mathrm{l}^{-1} \mathrm{~d}^{-1}$ in December 2007). However, contrary to what was observed for $\mathrm{NO}_{3}^{-}, \mathrm{NH}_{4}{ }^{+}$uptake showed high rates during winter, even higher than winter $\rho \mathrm{NO}_{3}$, averaging $133 \pm 200 \mathrm{nmol} \mathrm{l}^{-1} \mathrm{~d}^{-1}$ (maximum $435 \mathrm{nmol} \mathrm{l}^{-1} \mathrm{~d}^{-1}$ in May 2007).

Net nitrification $\left(\mathrm{rNO}_{3}\right.$, Fig. 5a) was always detected during this study, but rates were higher during spring and summer compared to winter conditions. Values of $\mathrm{rNO}_{3}$ averaged $74 \pm 121 \mathrm{nmol} \mathrm{l}^{-1} \mathrm{~d}^{-1}$ in surface waters (maximum rate $316 \mathrm{nmol} \mathrm{l}^{-1} \mathrm{~d}^{-1}$ concen- trated near the oxycline at $30 \mathrm{~m}$ in December 2006), while they were close to the detection limit in subsurface waters. Rates in winter averaged $21 \pm 22 \mathrm{nmol}^{-1}$ $\mathrm{d}^{-1}$ in the entire water column, with higher rates in surface waters $\left(20 \pm 25 \mathrm{nmol} \mathrm{l}^{-1} \mathrm{~d}^{-1}\right)$ than in deeper waters $\left(9 \pm 10 \mathrm{nmol} \mathrm{l}^{-1} \mathrm{~d}^{-1}\right)$.

After inhibition of ATU-sensitive microorganisms (i.e. $\mathrm{AOB}$ and probably also $\mathrm{AOA}$ ), partial nitrification showed the same pattern of distribution as net nitrification but mildly decreased to an average of $40 \pm$ $79 \mathrm{nmol} \mathrm{l}^{-1} \mathrm{~d}^{-1}$ in the whole water column. Although no significant difference was observed in near-bottom waters, a $30 \%$ decrease was observed in $\mathrm{NH}_{4}{ }^{+}$oxidation after ATU addition in surface waters (e.g. 80 versus $68 \mathrm{nmol} \mathrm{l}^{-1} \mathrm{~d}^{-1}$ in April 2008). Nevertheless, a local increase $\left(\sim 50 \mathrm{nmol} \mathrm{l}^{-1} \mathrm{~d}^{-1}\right)$ was detected in nearbottom waters during April and May 2007 (Fig. 5b).

Net $\mathrm{N}$ regeneration in the form of $\mathrm{NH}_{4}{ }^{+}\left(\mathrm{rNH}_{4}\right)$ showed maximum rates between the surface and the oxycline and often exceeded $500 \mathrm{nmol} \mathrm{l}^{-1} \mathrm{~d}^{-1}$ (Fig. 5c). Average values for spring and summer reached $526 \pm 584 \mathrm{nmol} \mathrm{l}^{-1} \mathrm{~d}^{-1}$, while winter values reached $462 \pm 360 \mathrm{nmol} \mathrm{l}^{-1} \mathrm{~d}^{-1}$. Rates of $\mathrm{rNH}_{4}$ peaked during spring 2007 and late summer 2008, with max-

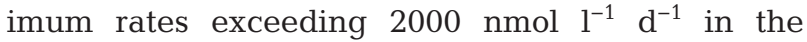
euphotic zone during March and April 2008 (Fig. 5c).

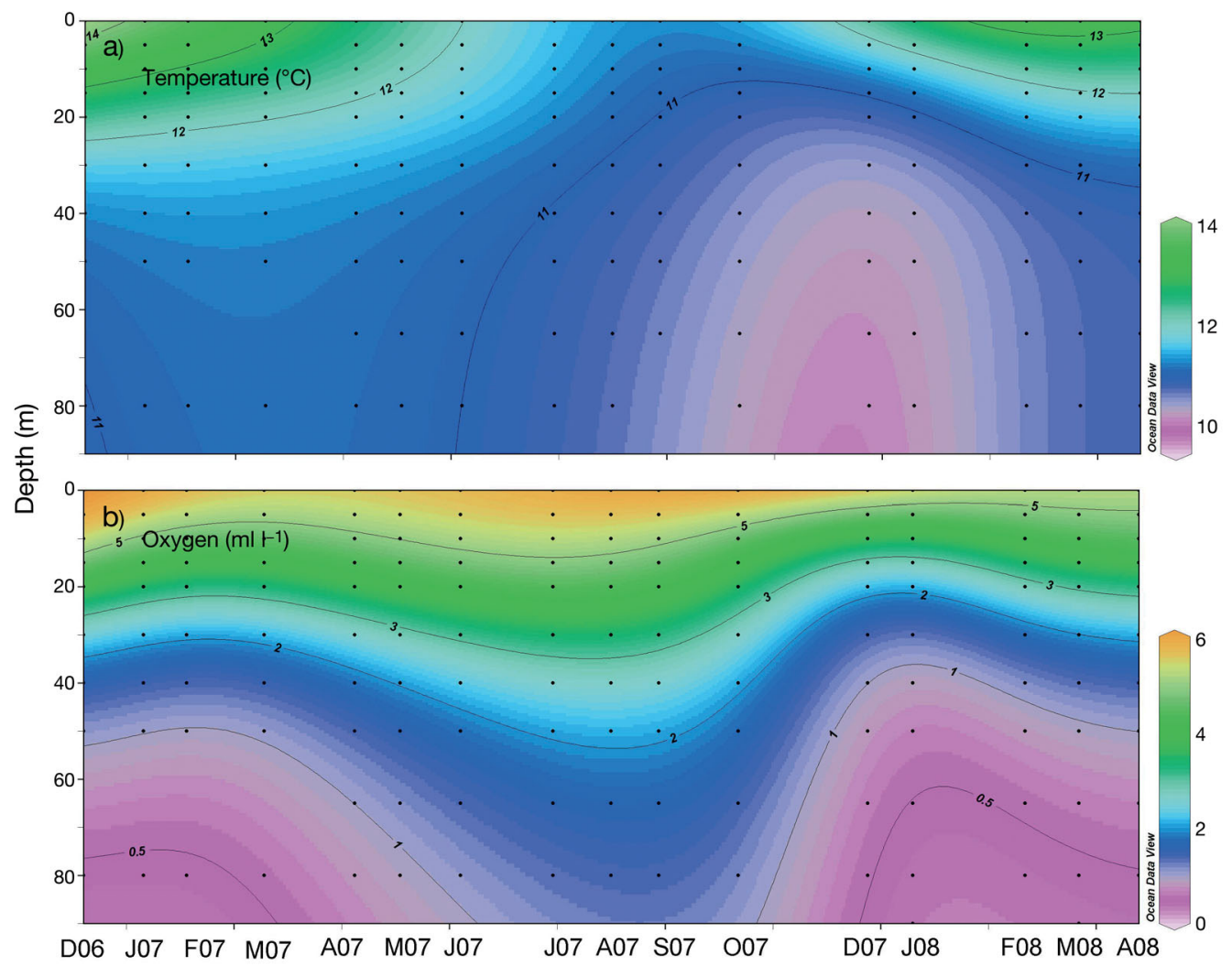

Fig. 2. Hydrographic parameters at time series Stn 18 (COPAS) between December 2006 and April 2008. (a) Temperature, (b) oxygen 

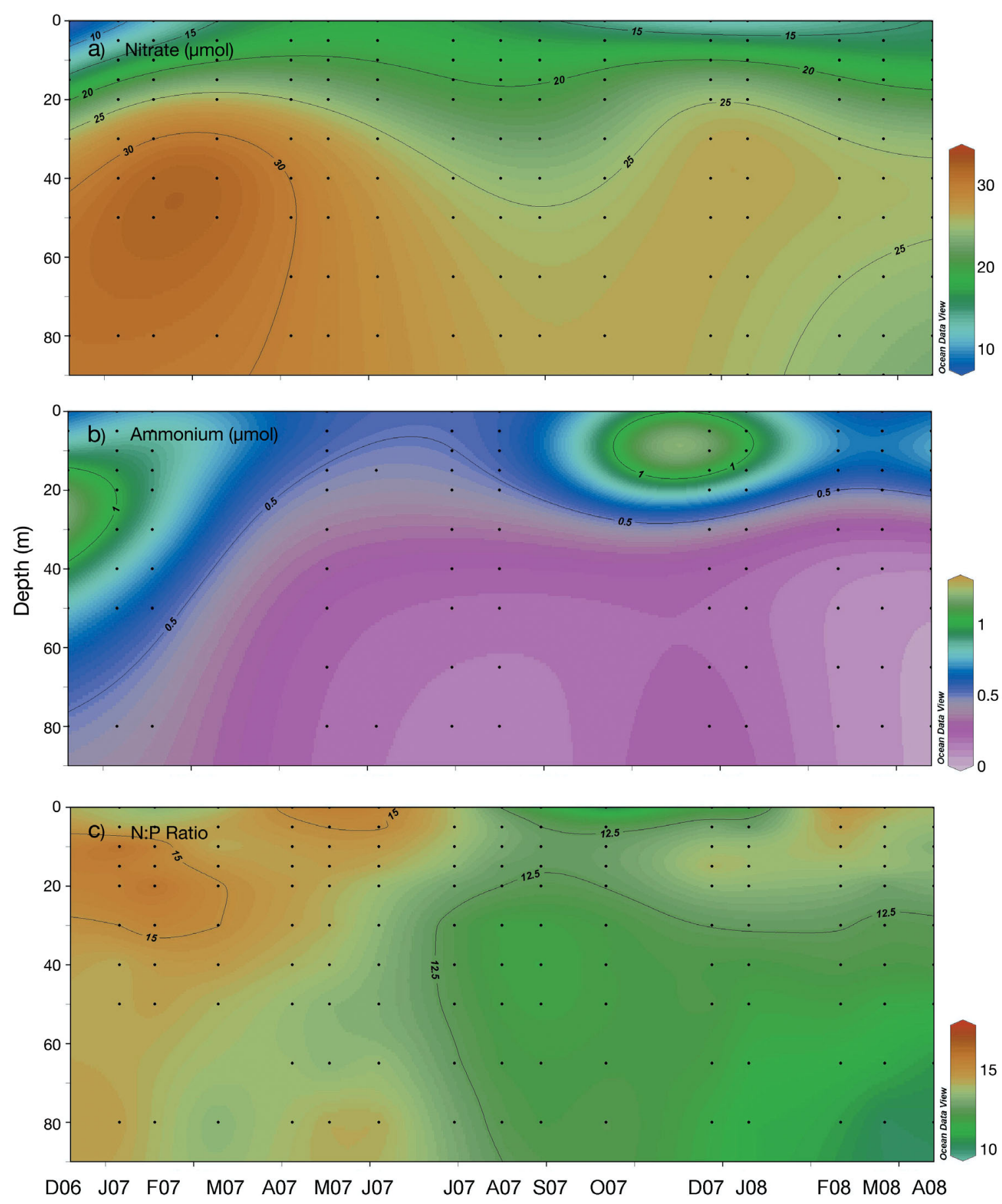

Fig. 3. Time series data of (a) $\mathrm{NO}_{3}{ }^{-}\left(\mu \mathrm{mol} \mathrm{l} l^{-1}\right)$, (b) $\mathrm{NH}_{4}{ }^{+}\left(\mu \mathrm{mol} \mathrm{l^{-1 }}\right)$, and (c) N:P ratio at time series Stn 18 (COPAS) between December 2006 and April 2008

\section{Nitrogen cycling during upwelling conditions}

The NICCHEX I cruise was carried out in January 2008, during active coastal upwelling conditions. Surface temperature reached $13.9^{\circ} \mathrm{C}$, while values decreased with depth to $10^{\circ} \mathrm{C}$ in near-bottom waters, indicating the presence of the ESSW (Fig. 6). The thermocline was located near $20 \mathrm{~m}$ depth while salinity remained constant around 34.5 in the entire water column. Dissolved oxygen 


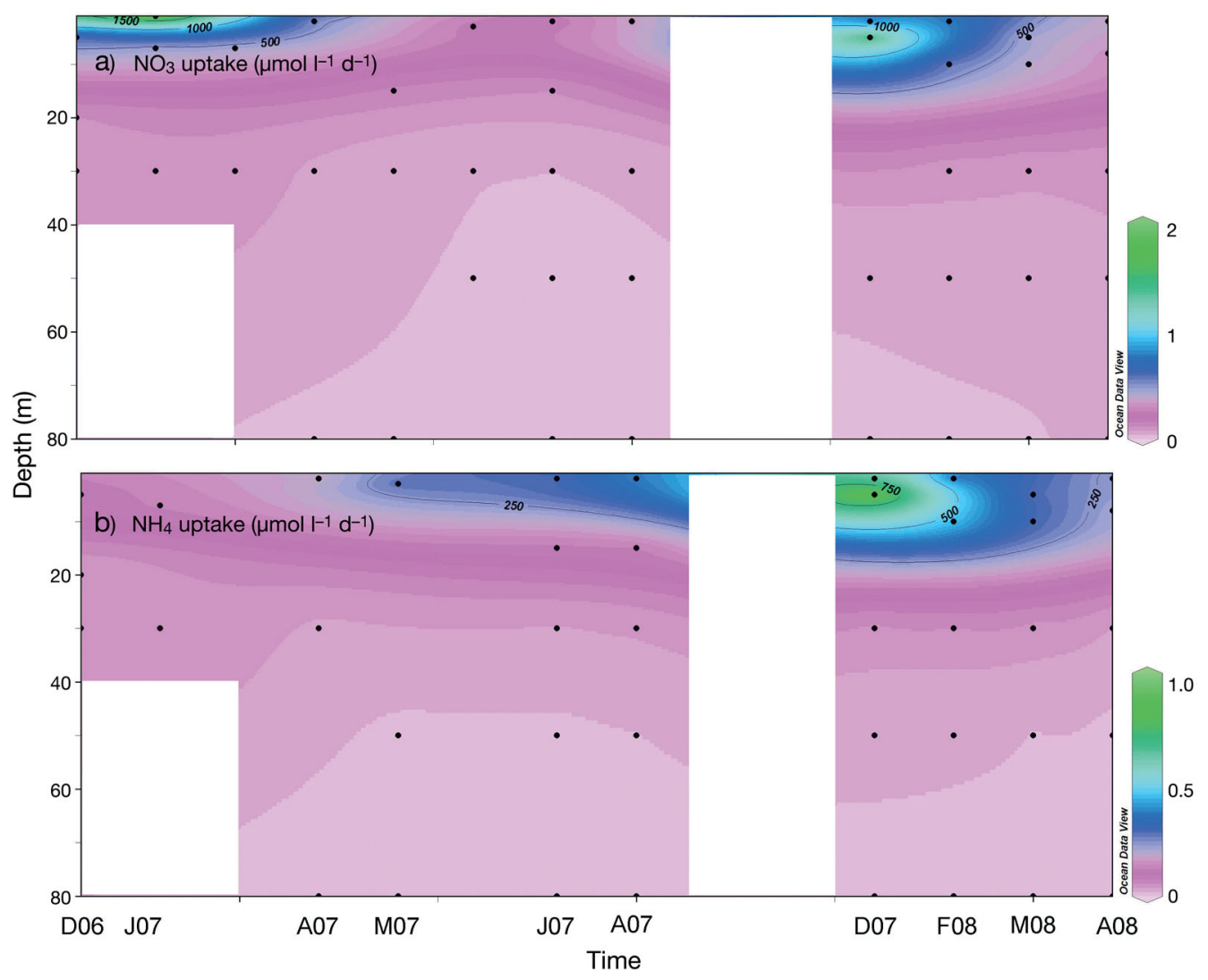

Fig. 4. Uptake rates of (a) $\mathrm{NO}_{3}{ }^{-}$and (b) $\mathrm{NH}_{4}{ }^{+}$(in nmol $\mathrm{l}^{-1} \mathrm{~d}^{-1}$ ) during the period December 2006 to April 2008 at $\mathrm{Stn} 18$ of the time series program

exceeded $6 \mathrm{ml} \mathrm{l}^{-1}$ in surface waters but decreased dramatically with depth. The base of the oxycline was located near $15 \mathrm{~m}$ depth, with values close to $1 \mathrm{ml} \mathrm{l}^{-1}$. Oxygen levels continued to decrease to $<0.2 \mathrm{ml} \mathrm{l}^{-1}$ at $50 \mathrm{~m}$ and reached $0.3 \mathrm{ml} \mathrm{l}^{-1}$ at $80 \mathrm{~m}$ depth.

$\mathrm{NO}_{3}{ }^{-}$concentrations (Fig. 7) were close to $0.7 \mu \mathrm{mol} \mathrm{^{-1 }}$ in surface waters, indicating intense utilization by phytoplankton, compared to winter conditions. A sharp nitracline followed, reaching $30 \mathrm{mmol} \mathrm{l}^{-1}$ and coincided with the oxycline. $\mathrm{NO}_{3}{ }^{-}$ concentrations decreased to $16 \mu \mathrm{mol} \mathrm{l^{-1 }}$ at $50 \mathrm{~m}$ depth coinciding with minimum oxygen conditions and were followed by a 2-fold increase in nearbottom waters.

$\mathrm{NO}_{2}{ }^{-}$concentrations were close to $0.1 \mu \mathrm{mol} \mathrm{l^{-1 }}$ in surface waters and increased to $0.5 \mu \mathrm{mol} \mathrm{l}^{-1}$ at $10 \mathrm{~m}$ depth, forming the primary $\mathrm{NO}_{2}{ }^{-}$maximum. A second peak $\left(0.2 \mu \mathrm{mol} \mathrm{l^{-1 }}\right)$ was observed at $70 \mathrm{~m}$ depth. $\mathrm{NH}_{4}{ }^{+}$distribution followed the trend observed for $\mathrm{NO}_{2}{ }^{-}$, with maximum values $\left(0.7 \mu \mathrm{mol} \mathrm{l}{ }^{-1}\right)$ at $10 \mathrm{~m}$ depth. Concentrations then decreased with depth, although a local accumulation of $0.2 \mu \mathrm{mol} \mathrm{l}^{-1}$ was observed at $70 \mathrm{~m}$ depth.
During $12 \mathrm{~h}$ incubations using water from $30 \mathrm{~m}$ depth, net nitrification $\left({ }^{15} \mathrm{NH}_{4}\right.$ with no inhibitor) was detected at low rates (Fig. 8), although $\mathrm{NO}_{2}{ }^{-}$and $\mathrm{NO}_{3}{ }^{-}$accumulated and $\mathrm{NH}_{4}{ }^{+}$levels remained constant (Table 2). In samples treated with ${ }^{15} \mathrm{NH}_{4}$ and sodium azide $\left(\mathrm{NaN}_{3}\right.$ for which $\mathrm{NO}_{2}^{-}$oxidation was expected to be inhibited), $\mathrm{NO}_{3}{ }^{-}+\mathrm{NO}_{2}{ }^{-}$accumulated during the last $6 \mathrm{~h}$ of incubation. In this case we obtained a rate of net ammonium oxidation $\left(\mathrm{NH}_{4} \mathrm{Ox}\right)$ of $18 \mathrm{nmol} \mathrm{l}^{-1} \mathrm{~h}^{-1}$ (Fig. 8).

In contrast, the rate of change for $\mathrm{NO}_{3}{ }^{-}+\mathrm{NO}_{2}{ }^{-}$in samples where net $\mathrm{NO}_{2}$ ox was evaluated $\left({ }^{15} \mathrm{NO}_{2}\right.$ addition combined with ATU, Table 3) showed high

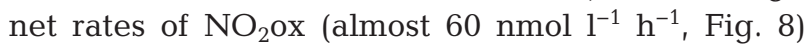
while $\mathrm{NO}_{2}^{-}$concentrations in the sample decreased (Table 3). Samples amended with ${ }^{15} \mathrm{NH}_{4}$ and treated with GC7 (a treatment expected to inhibit archaeal $\mathrm{NH}_{4}{ }^{+}$oxidation) revealed an accumulation of $\mathrm{NO}_{3}{ }^{-}+$ $\mathrm{NO}_{2}{ }^{-}$that could be attributed to bacterial $\mathrm{NH}_{4}{ }^{+}$oxidation (Table 2).

In experiments with water from $80 \mathrm{~m}$ depth, net nitrification rates for ${ }^{15} \mathrm{NH}_{4}$-amended samples were close to $20 \mathrm{nmol} \mathrm{l}^{-1} \mathrm{~h}^{-1}$ (Fig. 8), while nutrient evolution showed decreasing $\mathrm{NO}_{3}^{-}+\mathrm{NO}_{2}^{-}$concentrations 

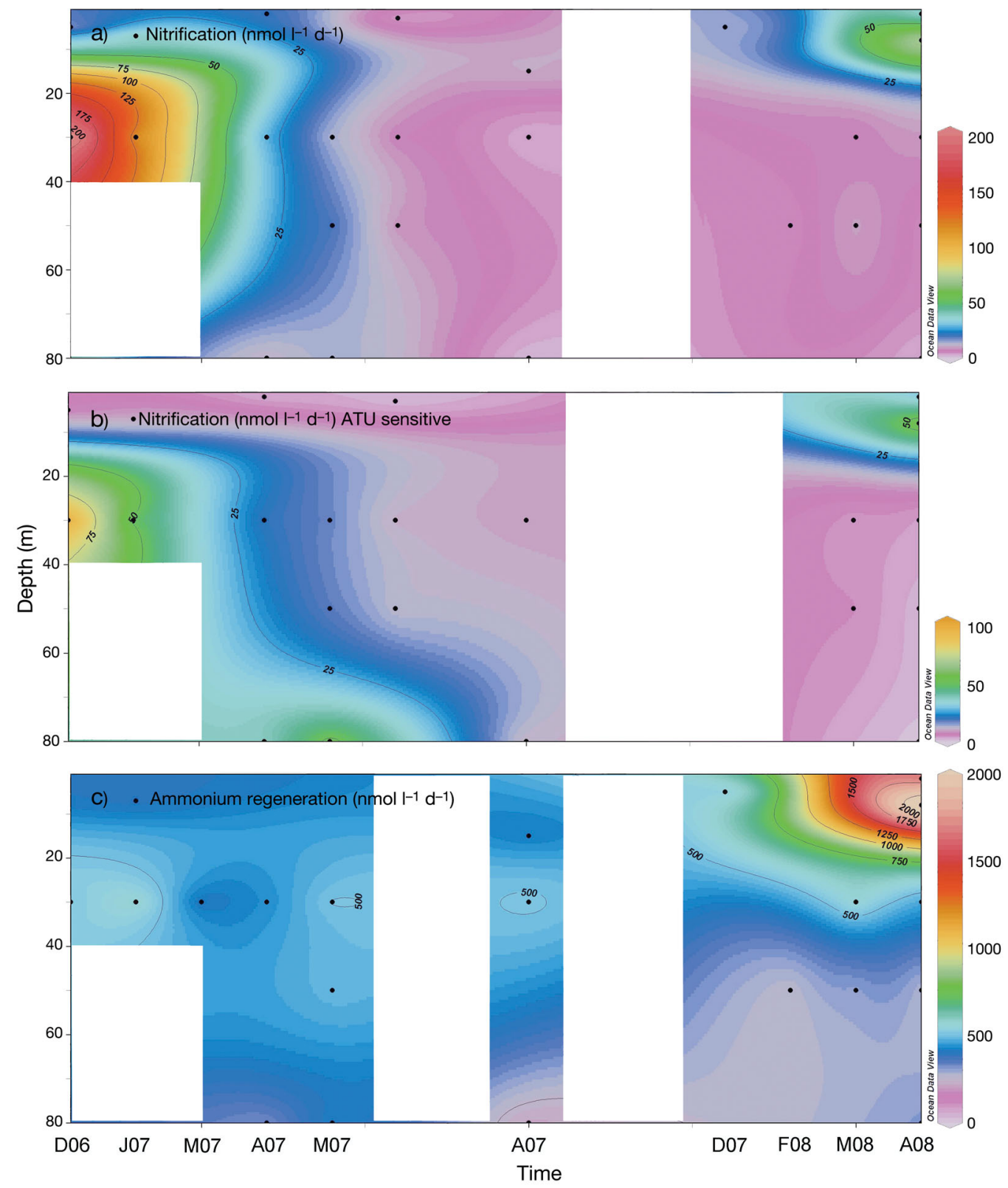

Fig. 5. Regeneration fluxes of $\mathrm{NH}_{4}^{+}\left(\mathrm{rNH}_{4}, \mathrm{nmol} \mathrm{l}^{-1} \mathrm{~d}^{-1}\right)$ and nitrification $\left(\mathrm{rNO}_{3}\right.$, in $\left.\mathrm{nmol} \mathrm{l}^{-1} \mathrm{~d}^{-1}\right)$ during the period December 2006 to April 2008. (a) Net nitrification, (b) nitrification after inhibition of allylthiourea (ATU)-sensitive microorganisms, (c) net $\mathrm{N}$ regeneration

and $\mathrm{NH}_{4}{ }^{+}$levels showed constant values (Table 2). Net $\mathrm{NH}_{4} \mathrm{ox}$ (obtained from samples amended with ${ }^{15} \mathrm{NH}_{4}$ and $\mathrm{NaN}_{3}$ ) showed $\mathrm{NH}_{4}{ }^{+}$oxidation rates of $12.5 \mathrm{nmol} \mathrm{l}^{-1} \mathrm{~h}^{-1}$ (Fig. 8). Samples amended with ${ }^{15} \mathrm{NH}_{4}$ and treated with GC7 (AOA inhibition) revealed an accumulation of $\mathrm{NO}_{3}^{-}+\mathrm{NO}_{2}^{-}$, while $\mathrm{NH}_{4}{ }^{+}$decreased (Table 2). They also showed high

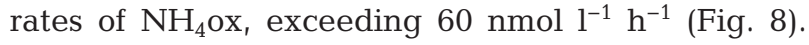
This suggests that the bacterial nitrifying community has the potential for high rates of $\mathrm{NH}_{4}{ }^{+}$oxidation, despite the low net rates obtained in the ${ }^{15} \mathrm{NH}_{4}$-only amended control. Concerning $\mathrm{NO}_{2} \mathrm{Ox}$, samples amended with ${ }^{15} \mathrm{NO}_{2}$ and ATU showed a net estimated rate of $\mathrm{NO}_{2} \mathrm{Ox}$ of $15 \mathrm{nmol} \mathrm{l}^{-1} \mathrm{~h}^{-1}$ (Fig. 8), which is almost equivalent to net $\mathrm{NH}_{4}{ }^{+}$oxidation rates for the same depth $\left(14 \mathrm{nmol} \mathrm{l}^{-1} \mathrm{~h}^{-1}\right)$. In contrast, $\mathrm{NO}_{2}{ }^{-}$ concentration did not vary significantly during the incubation period (Table 2), showing that consumption of $\mathrm{NO}_{2}{ }^{-}$was supported by its constant production (probably via archaeal $\mathrm{NH}_{4}{ }^{+}$oxidation). 


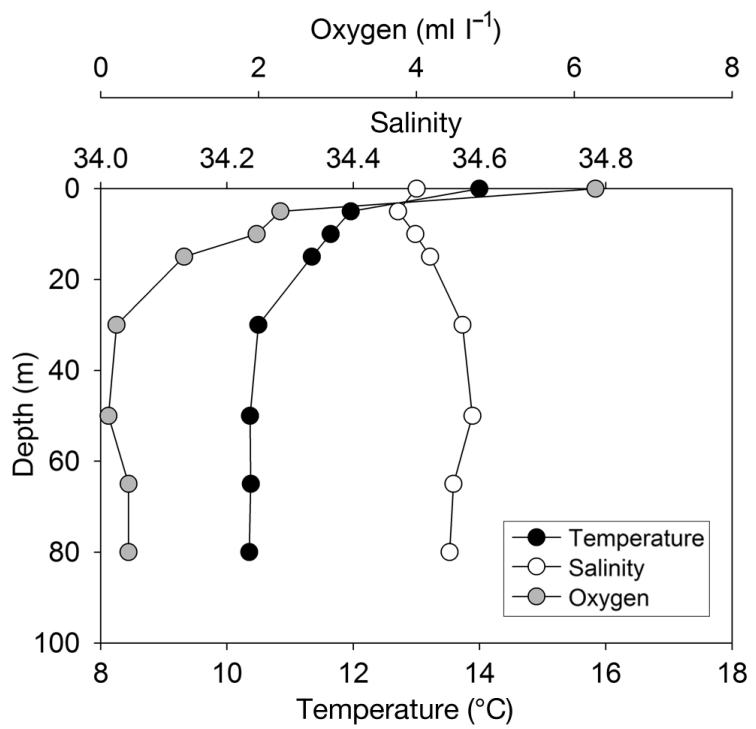

Fig. 6. Hydrographic conditions during the NICCHEX I experiment

\section{DISCUSSION}

During our study, the wind patterns and upwelling index off central Chile reflected the seasonality in the study area. Upwelling-favorable conditions were present during austral spring and summer, driven by southerly winds, and were followed by a northerly wind direction during winter (Sobarzo \& Djurfeldt 2004). According to measurements which determined the timing of the spring transition and the upwelling period as well as upwelling-favorable winds, the prevailing conditions can be characterized as fol-

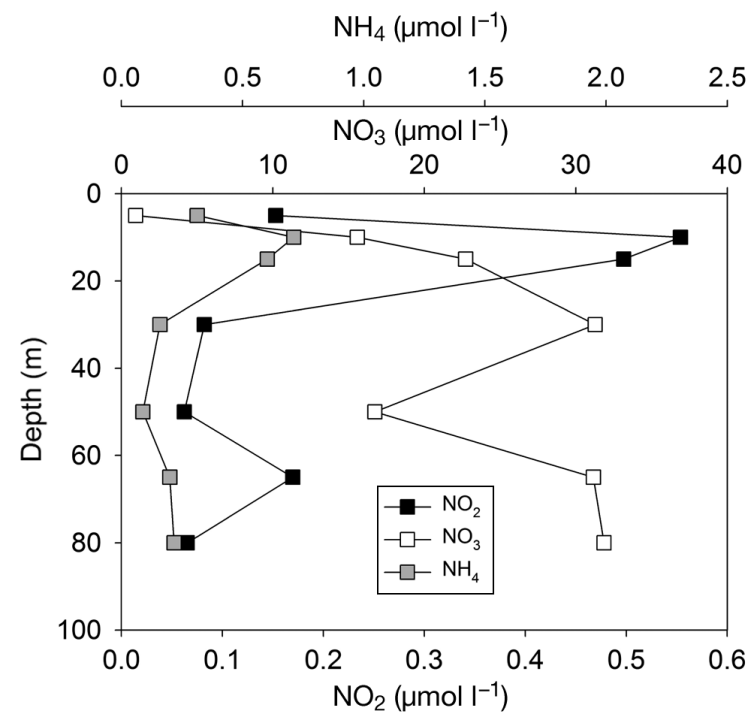

Fig. 7. Nutrient profiles of initial conditions for NICCHEX I experiments lows: upwelling from November 2006 to April 2007 and October 2007 to April 2008 (spring and summer), while the periods from May to September 2007 (fall and winter) did not have upwelling-favorable conditions (Galán et al. 2011).

Upwelling led to high levels of $\mathrm{NH}_{4}{ }^{+}$(often exceeding $1 \mu \mathrm{mol} \mathrm{l} \mathrm{l}^{-1}$ ). $\mathrm{NO}_{3}{ }^{-}$concentrations also showed very high values throughout the water column that resulted from the upwelling of $\mathrm{NO}_{3}{ }^{-}$-rich ESSW. The availability of both substrates allowed intense assimilation by photoautotrophs, but also intense recycling via $\mathrm{NH}_{4}{ }^{+}$regeneration and nitrification in the photic and aphotic layers of the water column (see Fig. 5).

\section{Seasonal trends in $\mathrm{NH}_{4}{ }^{+}$and $\mathrm{NO}_{3}{ }^{-}$utilization}

This study confirms that the coastal upwelling area off Concepción is a highly productive region (Daneri et al. 2000, Farías et al. 2009a,b). The $\mathrm{NO}_{3}{ }^{-}$uptake rates reported here are higher than those in the eastern South Pacific Ocean, which can reach 12.5 and $17.5 \mathrm{nmol} \mathrm{l}^{-1} \mathrm{~h}^{-1}$ off Peru and Costa Rica, respectively (Franck et al. 2005, Fernández et al. 2009). Although the spring season of 2007 is under-represented in our data (Fig. 4) and therefore the DIN uptake rates for that season might be underestimated, rates of $\mathrm{NH}_{4}{ }^{+}$ uptake presented here are also within the range of previous measurements in the Northeast Pacific $(0.32$ to $1.38 \mathrm{nmol}^{-1} \mathrm{~h}^{-1}$ in winter and 1.2 to $2.95 \mathrm{nmol} \mathrm{l}^{-1}$ $\mathrm{h}^{-1}$ in spring; Varela \& Harrison 1999).

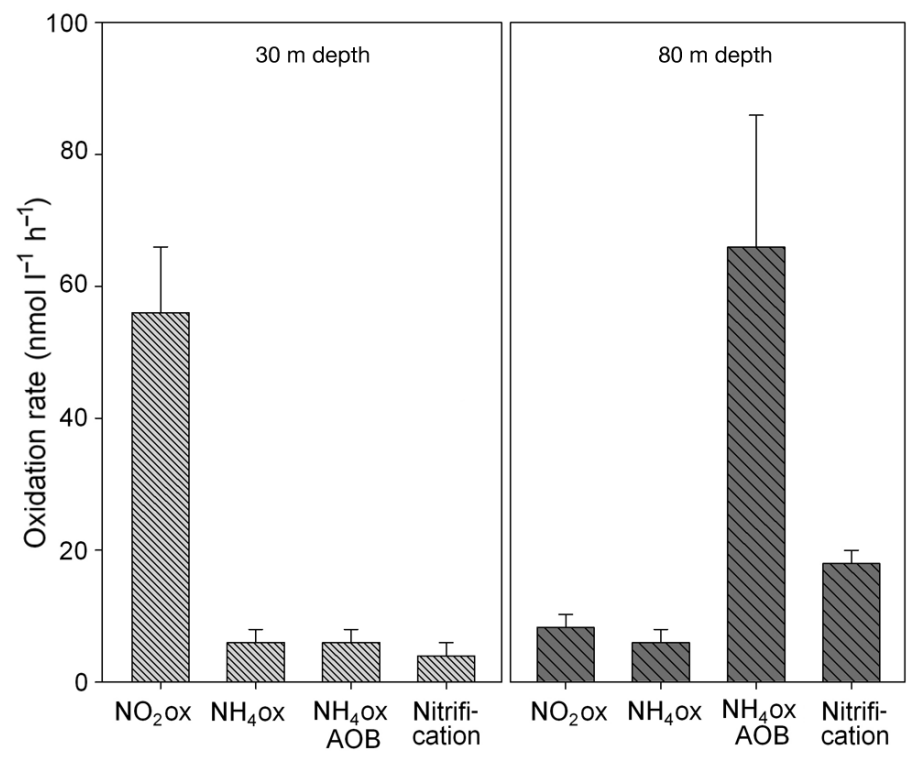

Fig. 8. Fluxes of net nitrification obtained through stable isotope assays. AOB: $\mathrm{NH}_{4}{ }^{+}$oxidizing bacteria, $\mathrm{NH}_{4} \mathrm{Ox}$ : $\mathrm{NH}_{4}{ }^{+}$oxidation; $\mathrm{NO}_{2} \mathrm{Ox}: \mathrm{NO}_{2}^{-}$oxidation 
Table 2. Evolution of nutrient concentrations during tracer incubations carried out during the NICCHEX I experiments. Rates are reported for experiments carried out at 30 and $80 \mathrm{~m}$ depth. Values are reported as mean \pm SD. NA: not applicable

\begin{tabular}{|c|c|c|c|c|c|c|c|}
\hline \multirow{2}{*}{$\begin{array}{l}\text { Depth } \\
\text { (m) }\end{array}$} & \multirow{2}{*}{$\begin{array}{c}\text { Treatment } \\
\text { (tracer/inhibitor) }\end{array}$} & \multicolumn{3}{|c|}{$\mathrm{NO}_{3}^{-}+\mathrm{NO}_{2}^{-}$concentration $\left(\mu \mathrm{mol} \mathrm{l} l^{-1}\right)$} & \multicolumn{3}{|c|}{$\mathrm{NH}_{4}^{+}$concentration $\left(\mu \mathrm{mol} \mathrm{l}{ }^{-1}\right)$} \\
\hline & & $T_{0}$ & $T_{0}+6 \mathrm{~h}$ & $T_{0}+12 \mathrm{~h}$ & $T_{0}$ & $T_{0}+6 \mathrm{~h}$ & $T_{0}+12 \mathrm{~h}$ \\
\hline 30 & $\begin{array}{l}{ }^{15} \mathrm{NH}_{4} \\
{ }^{15} \mathrm{NH}_{4} \text { /azide } \\
{ }^{15} \mathrm{NH}_{4} \text { /azide/GC7 }\end{array}$ & $\begin{array}{r}20.14 \pm 0.28 \\
29.22 \pm 0.25 \\
24.9 \pm 0.06\end{array}$ & $\begin{array}{c}28.32 \pm 0.23 \\
18.74 \pm 0.098 \\
\text { NA }\end{array}$ & $\begin{aligned} 28.97 & \pm 0.23 \\
26.35 & \pm 0.011 \\
32 & \pm 11.5\end{aligned}$ & $\begin{array}{c}0.02 \\
0.058 \\
0.02\end{array}$ & $\begin{array}{c}0.03 \pm 0.02 \\
0.003 \pm 0 \\
\text { NA }\end{array}$ & $\begin{array}{c}0.02 \pm 0.02 \\
0.002 \pm 0 \\
3.68\end{array}$ \\
\hline 80 & $\begin{array}{l}{ }^{15} \mathrm{NH}_{4} \\
{ }^{15} \mathrm{NH}_{4} \text { /azide } \\
{ }^{15} \mathrm{NH}_{4} \text { /azide/GC7 }\end{array}$ & $\begin{array}{c}25.98 \pm 0.08 \\
20.23 \pm 0.11 \\
23.9\end{array}$ & $\begin{array}{c}26.21 \pm 0.067 \\
22.75 \pm 0.61 \\
\text { NA }\end{array}$ & $\begin{array}{l}16.12 \pm 0.23 \\
26.69 \pm 0.25 \\
22.61 \pm 3.035\end{array}$ & $\begin{array}{l}2.56 \\
2.56 \\
2.56\end{array}$ & $\begin{array}{r}4.05 \pm 0.39 \\
2.844 \pm 0.45 \\
\text { NA }\end{array}$ & $\begin{array}{c}3.66 \pm 0.085 \\
2.95 \pm 1.023 \\
2.09\end{array}$ \\
\hline
\end{tabular}

Table 3. Evolution of $\mathrm{NO}_{2}^{-}$concentrations during tracer incubations carried out during the NICCHEX I experiments. Values are reported as mean \pm SD. ATU: allylthiourea

\begin{tabular}{|c|c|c|c|c|c|c|c|}
\hline \multirow{2}{*}{$\begin{array}{l}\text { Depth } \\
\text { (m) }\end{array}$} & \multirow{2}{*}{$\begin{array}{c}\text { Treatment } \\
\text { (tracer/inhibitor) }\end{array}$} & \multicolumn{3}{|c|}{$\mathrm{NO}_{3}^{-}+\mathrm{NO}_{2}^{-}$concentration $\left(\mu \mathrm{mol} 1^{-1}\right)$} & \multicolumn{3}{|c|}{$\mathrm{NO}_{2}^{-}$concentration $\left(\mu \mathrm{mol} l^{-1}\right)$} \\
\hline & & $T_{0}$ & $T_{0}+6 \mathrm{~h}$ & $T_{0}+12 \mathrm{~h}$ & $T_{0}$ & $T_{0}+6 \mathrm{~h}$ & $T_{0}+12 \mathrm{~h}$ \\
\hline 30 & ${ }^{15} \mathrm{NO}_{2} / \mathrm{ATU}$ & $27.11 \pm 0.47$ & $26.69 \pm 0.47$ & $19.42 \pm 0.33$ & 3.21 & $3.12 \pm 0.02$ & $0.19 \pm 0.14$ \\
\hline 30 & ${ }^{15} \mathrm{NO}_{2} / \mathrm{ATU}$ & $26.75 \pm 0.1$ & $28.53 \pm 0.38$ & $22.45 \pm 0.22$ & $3.49 \pm 0.2$ & $3.5 \pm 0.2$ & $3.6 \pm 0.5$ \\
\hline
\end{tabular}

Maximum uptake of $\mathrm{NO}_{3}{ }^{-}$and $\mathrm{NH}_{4}{ }^{+}$occurred during spring and summer, in accordance with the intensification of coastal upwelling and the subsequent increased availability of nutrients and chlorophyll a (chl a; Galán et al. 2011). Rates of surface ammonium assimilation $\left(\rho \mathrm{NH}_{4}\right)$ were lower than $\mathrm{NO}_{3}{ }^{-}$uptake during summer, but very closely approached the values of $\mathrm{\rho NO}_{3}$ concentrations during the winter season (maximum $435 \mathrm{nmol} \mathrm{l}^{-1} \mathrm{~d}^{-1}$ for $\mathrm{\rho NH}_{4}$ versus $354 \mathrm{nmol}$ $\mathrm{l}^{-1} \mathrm{~d}^{-1} \mathrm{\rho NO}_{3}$, Fig. 4). The chl a levels reported for the study area for the same period (20 to $40 \mathrm{mg} \mathrm{m}^{-2}$ for winter versus 60 to $300 \mathrm{mg} \mathrm{m}^{-2}$ for summer; Galán et al. 2011) also support the idea that this system is sustained by regenerated production rather than by new production during the non-upwelling periods of the year. These observations suggest that total primary production levels encountered off central Chile are related not only to $\mathrm{NO}_{3}{ }^{-}$assimilation, but are also linked to concurrent and subsequent $\mathrm{NH}_{4}{ }^{+}$uptake by phytoplankton, a feature that also characterizes other coastal systems (Dugdale et al. 2007). We cannot rule out that other groups intervene in the competition for $\mathrm{NH}_{4}{ }^{+}$utilization in the euphotic zone in this system: picoeukaryots and fungi are potentially important components of the microbial community in the eastern South Pacific (Grob et al. 2007, Gutierrez et al. 2010), but more information is necessary to determine their role in the local $\mathrm{N}$ cycle.

DIN uptake during winter and spring is linked to $\mathrm{N}$ regenerating processes occurring simultaneously in the water column. Indeed, $\mathrm{NH}_{4}{ }^{+}$regeneration activity was high and sustained during the entire year
(Fig. 5), representing a constant source of substrate for photoautotrophic assimilation (Bode et al. 2004). Our data on $\mathrm{NH}_{4}^{+}$production by in situ microbial regeneration (exceeding $1 \mu \mathrm{mol} \mathrm{l}^{-1} \mathrm{~d}^{-1}$ ) showed higher fluxes compared to the capacity of nitrification to remove $\mathrm{NH}_{4}{ }^{+}$in the upper water column (Fig. 5), leading to strong sporadic $\mathrm{NH}_{4}{ }^{+}$accumulation. Furthermore, $\mathrm{NH}_{4}^{+}$regeneration fluxes could support the demand of phytoplankton and picoplankton (archaea and bacteria) for $\mathrm{N}$ (maximum rates close to $1.8 \mu \mathrm{mol} \mathrm{l}^{-1} \mathrm{~d}^{-1}$ during spring 2007), which highlights the biogeochemical importance of this process.

Although it is less intense compared to $\mathrm{NH}_{4}{ }^{+}$ regeneration, an important fraction of $\mathrm{NH}_{4}^{+}$utilization in this study can be attributed to nitrifying activity via $\mathrm{NH}_{4}{ }^{+}$oxidizers. This process showed significant rates in the entire water column, particularly during spring and summer 2006 to 2007 and late summer 2008, but was mostly constrained to the oxycline and suboxic layers (Fig. 5), suggesting a nonnegligible effect of dissolved oxygen concentrations on the intensity of this flux.

Our findings confirm studies in the eastern South Pacific, which showed that nitrification is an active process with maximum significance during spring and summer (Fernández et al. 2009). In particular, nitrifying activity might have the potential for removing up to $700 \mathrm{nmol} \mathrm{l}^{-1} \mathrm{~d}^{-1}$ of $\mathrm{NH}_{4}{ }^{+}$off central Chile (Molina \& Fariás 2009), supporting our view of the importance of $\mathrm{NH}_{4}{ }^{+}$oxidizers (bacteria and archaea) for channeling $\mathrm{NH}_{4}{ }^{+}$into chemosynthetic pathways. Regeneration of $\mathrm{NH}_{4}{ }^{+}$is concurrent with intermittent 
nitrification fluxes in surface and subsurface waters, with intense vertical variability that might be related to oxygen dynamics.

\section{$\mathrm{NH}_{4}{ }^{+}$and $\mathrm{NO}_{2}{ }^{-}$oxidation}

In oxygen-deficient waters, nitrification can act as a critical process linking regeneration of $\mathrm{N}$ to its eventual loss as $\mathrm{N}_{2}$ or $\mathrm{N}_{2} \mathrm{O}$ via denitrification and anammox. Nitrification is carried out by 2 independent steps involving $\mathrm{NH}_{4}{ }^{+}$and $\mathrm{NO}_{2}{ }^{-}$oxidation. It has long been considered as a tightly coupled process where the rate of $\mathrm{NH}_{4}{ }^{+}$oxidation is equivalent to the rates of $\mathrm{NO}_{2}{ }^{-}$oxidation and $\mathrm{NO}_{3}{ }^{-}$production, therefore avoiding significant $\mathrm{NO}_{2}{ }^{-}$accumulation. However, field data provide increasing evidence of uncoupled functioning of nitrification in upwelling areas (Clark et al. 2011). Factors influencing the interaction of the 2 steps of nitrification $\left(\mathrm{NH}_{4}{ }^{+}\right.$and $\mathrm{NO}_{2}{ }^{-}$oxidation) and the capacity of the former to sustain the latter include variables such as light (Guerrero \& Jones 1996a,b), pH, substrate availability (Grundle \& Juniper 2011), and oxygen (Ward 2008). In the case of central Chile, hypoxic conditions prevail during the most productive season of the year, and oxygen levels in the water column can seasonally change from oxic in winter to suboxic $\left(\leq 11 \mu \mathrm{mol} \mathrm{l}^{-1} \mathrm{O}_{2}\right.$ ) or even anoxic levels in spring and summer. The response of nitrifying communities to such oxygen gradients might explain the variability in nitrification rates observed during this study.

Low oxygen levels can benefit nitrifying communities, as these often consist of microaerophiles. However, the specific effect of oxygen on nitrifying microorganisms has mostly been studied in $\mathrm{NH}_{4}{ }^{+}$oxidizers. Carlucci \& McNally (1969) and Goreau et al. (1980) found that aerobic AOB could remain active and even increase their growth rates and the ratio of $\mathrm{N}_{2} \mathrm{O} / \mathrm{NO}_{2}{ }^{-}$production at low $\mathrm{O}_{2}$ concentrations. On the other hand, Ginestet et al. (1998) estimated kinetic parameters of both $\mathrm{NH}_{4}{ }^{+}$and $\mathrm{NO}_{2}{ }^{-}$oxidation by oxygen depletion due to substrate consumption in pure cultures, and concluded that $\mathrm{NH}_{4}{ }^{+}$oxidizers are more tolerant to low oxygen levels than $\mathrm{NO}_{2}{ }^{-}$oxidizers. The determination of the biomass index based on the substrate utilization rate revealed that low levels of $\mathrm{O}_{2}$ doubled the growth yield of ammonium oxidizers, therefore compensating for the reduced specific substrate utilization. In contrast, $\mathrm{NO}_{2} \mathrm{Ox}$ was strongly inhibited by $0.5 \mathrm{mg} \mathrm{l}^{-1}$ of $\mathrm{O}_{2}$, with no increase in growth yield.
In this study, $\mathrm{NO}_{2} \mathrm{ox}$ decreased significantly as oxygen levels dropped, whereas $\mathrm{NH}_{4}$ ox did not show differences at different oxygen levels. At the oxycline, rates of $\mathrm{NO}_{2}^{-}$oxidation seem to be uncoupled from $\mathrm{NH}_{4}{ }^{+}$oxidation (Fig. 8), with $\mathrm{NO}_{2}{ }^{-}$oxidizers having a higher potential for producing $\mathrm{NO}_{3}{ }^{-}$than $\mathrm{NH}_{4}{ }^{+}$oxidizers for producing $\mathrm{NO}_{2}{ }^{-}$(see Tables 2 \& 3). The difference between $\mathrm{rNO}_{3}$ and $\mathrm{NO}_{2} \mathrm{Ox}$ could also reflect that $\mathrm{NO}_{2}{ }^{-}$-producing processes (such as denitrification or excretion by phytoplantkton) sustain $\mathrm{NO}_{2}{ }^{-}$oxidation, as has been suggested for other systems (Clark et al. 2011).

In near-bottom waters, on the other hand, $\mathrm{NH}_{4}{ }^{+}$ and $\mathrm{NO}_{2}{ }^{-}$oxidation fluxes seem to be coupled within the bacterial community despite low oxygen levels (Fig. 8 and Tables $2 \& 3$ ). Sporadic $\mathrm{NO}_{2}{ }^{-}$accumulations at this depth might result from the interaction of nitrification with denitrification and anammox occurring at high rates, as shown by data from sediment and bottom water in the study area (Farías et al. 2004, Galán et al. 2011).

Concerning nutrient availability as a controlling factor in nitrification coupling, nitrifying communities such as Nitrosococcus oceani may not depend on the direct release of $\mathrm{NH}_{4}{ }^{+}$to survive and might be able to reduce urea into $\mathrm{NH}_{4}{ }^{+}$in order to produce $\mathrm{NO}_{2}{ }^{-}$(Klotz et al. 2006). Concentrations of urea are high off central Chile, ranging between 0.2 and $1 \mu \mathrm{mol} \mathrm{l}^{-1}$ in winter and spring, respectively (PérezAragón et al. 2011). Therefore, it is possible that $\mathrm{NH}_{4}{ }^{+}$-oxidizing communities use alternative substrates in this system.

Community composition also needs to be taken into account when analyzing these results, as the coupling between NOB and AOA has not yet been demonstrated experimentally. A first indication of efficient coupling between these communities comes from our experiments, which proved that a fraction of the ambient $\mathrm{NH}_{4}{ }^{+}$was being oxidized by AOA (Fig. 5). Further evidence comes from a study carried out in the North Pacific, where a correlation was found between the distribution of close relatives of the $\mathrm{NO}_{2}{ }^{-}$oxidizer Nitrospina and AOA, which suggested possible interactions between these groups (Mincer et al. 2007), while a tight correlation was also observed between $\mathrm{NO}_{2}{ }^{-}$distribution and AOA activity (Beman et al. 2010). Therefore, it is possible that the coupling of both steps of nitrification $\left(\mathrm{NH}_{4}{ }^{+}\right.$and $\mathrm{NO}_{2}{ }^{-}$oxidation) can be carried out independently of the composition of the community of nitrifiers (i.e. the percentage of archaea within $\mathrm{NH}_{4}{ }^{+}$oxidizing microorganisms in the sample). 


\section{Role of $\mathrm{NH}_{4}{ }^{+}$oxidizing archaea and bacteria}

The vertical variability of $\mathrm{NH}_{4}{ }^{+}$and $\mathrm{NO}_{2}^{-}$oxidation in the Chilean upwelling system seem to be related to the main groups intervening in DIN regeneration, and to the relative importance of Crenarchaeota aerobic $\mathrm{NH}_{4}{ }^{+}$oxidizers (Könneke et al. 2005). As reported by recent studies in the area (Molina et al. 2010, Belmar et al. 2011), retrieved sequences of amoA (the gene involved in $\mathrm{NH}_{4}{ }^{+}$oxidation) and cell counts indicate that Crenarchaeota could be highly abundant and diverse in Oxygen Minimum Zones of northern Chile. Furthermore, although the physiology of this community is not well understood, it is known that they are particularly active (based on qPCR assays) under oxygendeficient, nutrient-rich conditions and can be equal or more abundant than AOB in this system (Molina et al. 2010). According to previous studies using GC7 as an AOA inhibitor (Farías et al. 2009b), their influence is also expected to be high in hypoxic waters off central Chile.

Some archaea have higher affinity for $\mathrm{NH}_{4}{ }^{+}$than most AOB (Martens-Habbena et al. 2009), which would give this group a comparative advantage in $\mathrm{NH}_{4}{ }^{+}$utilization. This is confirmed by our processoriented experiments that allowed separately approaching the activity of $\mathrm{AOA}$ and $\mathrm{AOB}$, as well as their possible interaction. Our results show that a variable fraction of the observed nitrification fluxes could have been performed by AOA. Also, the inhibition of archaeal ammonium oxidation resulted in high rates of bacterial nitrification in the suboxic near-bottom waters $(80 \mathrm{~m})$ as opposed to the oxycline (30 m), where no significant changes were observed (Fig. 8). Based on this, AOA groups might play a distinct role in both oxic and suboxic conditions, as found by Beman et al. (2008) and Santoro et al. (2010). However, bacterial $\mathrm{NH}_{4}{ }^{+}$oxidation might benefit from low oxygen concentrations, as shown by high fluxes in near-bottom suboxic waters (Fig. 8).

In summary, this study suggests that the seasonal upwelling system off central Chile is a highly productive region, in which primary production is sustained by $\mathrm{NO}_{3}{ }^{-}$as well as $\mathrm{NH}_{4}{ }^{+}$uptake in summer and winter. Also, DIN regeneration via nitrification is intense and is highly influenced by oxygen levels, which determine the capacity of the nitrifying community $\left(\mathrm{NH}_{4}{ }^{+}\right.$and $\mathrm{NO}_{2}{ }^{-}$oxidizers) to act at equivalent rates. Archaeal $\mathrm{NH}_{4}{ }^{+}$oxidizers are potentially important players in oxic and oxycline conditions, while bacterial $\mathrm{NH}_{4}{ }^{+}$oxidation is important in suboxic layers.
Acknowledgements. This research was funded by Fondecyt grant 1090446 and project ECOS-CONICYT C09B02. We thank M. E. Alcamán for valuable help in experiments and sample analysis, and the COPAS time series program for access to this experimental platform. The crew of RV 'Kay Kay (II)' and Dichato Marine Station of the Universidad de Concepción provided valuable help during field work and laboratory analysis. This study was finalized in the frame of the International Associated Laboratory MORFUN.

\section{LITERATURE CITED}

Alcaraz M, Saiz E, Estrada M (1994) Excretion of ammonia by zooplankton and its potential contribution to nitrogen requirements for primary production in the Catalan Sea (NW Mediterranean). Mar Biol 119:69-76

Belmar L, Molina V, Ulloa O (2011) Abundance and phylogenetic identity of archaeoplankton in the permanent oxygen minimum zone of the eastern tropical south Pacific. FEMS Microbiol Ecol 78:314-326

Beman JM, Popp BN, Francis CA (2008) Molecular and biogeochemical evidence for ammonia oxidation by marine Crenarchaeota in the Gulf of California. ISME J 2:429-441

> Beman JM, Sachdeva R, Fuhrman JA (2010) Population ecology of nitrifying archaea and bacteria in the southern California Bight. Environ Microbiol 12:1282-1292

> Bode A, Barquero S, Gonzalez N, Alvarez-Ossorio MT, Varela M (2004) Contribution of heterotrophic plankton to nitrogen regeneration in the upwelling ecosystem of A Coruña (NW Spain). J Plankton Res 26:11-28

Bronk D (2002) Dynamics of DON. In: Hansell DA, Carlson CA (eds) Biogeochemistry of marine dissolved organic matter. Academic Press, San Diego, CA, p 186-207

Carlucci AF, McNally PM (1969) Nitrification by marine bacteria in low concentrations of substrate and oxygen. Limnol Oceanogr 14:736-739

Clark D, Miller PI, Malcolm E, Woodward S, Rees A (2011) Inorganic nitrogen assimilation and regeneration in the coastal upwelling region of the Iberian Peninsula. Limnol Oceanogr 56:1689-1702

Daneri G, Dellarossa V, Quiñones R, Jacob B, Montero P, Ulloa O (2000) Primary production and community respiration in the Humboldt Current System off Chile and associated oceanic areas. Mar Ecol Prog Ser 197:41-49

$>$ Dugdale RC, Goering JJ (1967) Uptake of new and regenerated forms of nitrogen in primary productivity. Limnol Oceanogr 12:196-206

> Dugdale RC, Wilkerson FP, Hogue VE, Marchi A (2007) The role of ammonium and nitrate in spring bloom development in San Francisco Bay. Estuar Coast Shelf Sci 73: $17-29$

Eppley R, Peterson BJ (1979) Particulate organic matter flux and planktonic new production in the deep ocean. Nature 282:677-679

> Farías L, Graco M, Ulloa O (2004) Temporal variability of nitrogen cycling in continental-shelf sediments of the upwelling ecosystem off central Chile. Deep-Sea Res II 51:2491-2505

Farías L, Castro-González M, Cornejo M, Charpentier J, Faúndez J, Boontanon N, Yoshida N (2009a) Denitrification and nitrous oxide cycling within the upper oxycline of the oxygen minimum zone off the eastern tropical 
South Pacific. Limnol Oceanogr 54:132-144

Farías L, Fernandez C, Faundez J, Cornejo M, Alcaman M (2009b) Chemolithoautotrophic production mediating the cycling of the greenhouse gases $\mathrm{N}_{2} \mathrm{O}$ and $\mathrm{CH}_{4}$ in an upwelling ecosystem. Biogeosciences 6:3053-3069

Fernández C, Farias L, Alcamán M (2009) Primary production and nitrogen regeneration processes in surface waters of the Peruvian upwelling system. Prog Oceanogr 83:159-168

Franck VM, Smith G, Bruland K, Brzezinski MA (2005) Comparison of size-dependent carbon, nitrate, and silicic acid uptake rates in high- and low-iron waters. Limnol Oceanogr 50:825-838

Galán A, Molina V, Belmar L, Ulloa O (2011) Temporal variability and phylogenetic characterization of planktonic anammox bacteria in the coastal upwelling ecosystem off central Chile. Prog Oceanogr 92:110-120

> Ginestet P, Audic J, Urbain V, Block J (1998) Estimation of nitrifying bacterial activities by measuring oxygen uptake in the presence of the metabolic inhibitors allylthiourea and azide. Appl Environ Microbiol 64: 2266-2268

Goreau TJ, Kaplan WA, Wofsy J, McElroy M, Valois FW, Watson SW (1980) Production of $\mathrm{NO}_{2}^{-}$and $\mathrm{N}_{2} \mathrm{O}$ by nitrifying bacteria at reduced concentrations of oxygen. Appl Environ Microbiol 40:526-532

Grasshoff K, Ehrhardt M, Kremling K (1983) Methods of seawater analysis. Verlag Chemie, Weinheim

Grob C, Ulloa O, Claustre H, Alarcón G, Marie D (2007) Contribution of picoplankton to the total particulate organic carbon concentration in the eastern South Pacific. Biogeosciences 4:837-852

> Grundle DS, Juniper SK (2011) Nitrification from the lower euphotic zone to the suboxic waters of a highly productive British Columbia fjord. Mar Chem 126:173-181

Guerrero M, Jones R (1996a) Photoinhibition of marine nitrifying bacteria. I. Wavelength response. Mar Ecol Prog Ser 141:183-192

Guerrero M, Jones R (1996b) Photoinhibition of marine nitrifying bacteria. II. Dark recovery after monochromatic or polychromatic irradiation. Mar Ecol Prog Ser 141:193-198

Gutierrez M, Pantoja S, Quiñones R, Gonzalez R (2010) First record of filamentous fungi in the coastal upwelling ecosystem off central Chile. Gayana 74:66-73

Holmes RH, Aminot A, Kérouel R, Hooker BA, Peterson BJ (1999) A simple and precise method for measuring ammonium in marine and freshwater ecosystems. Can J Fish Aquat Sci 56:1801-1808

> Jansson BP, Malandrin L, Johansson HE (2000) Cell cycle arrest in archaea by the hypusination inhibitor N1guanyl-1,7-diaminoheptane. J Bacteriol 182:1158-1161

Klotz MG, Arp D, Patrick S, Chain G and others (2006) Complete genome sequence of the marine, chemolithoautotrophic, ammonia-oxidizing bacterium Nitrosococcus oceani ATCC 19707. Appl Environ Microbiol 72: 6299-6315

Könneke M, Bernhard A, de la Torre J, Walker C, Waterbury J, Stahl D (2005) Isolation of an autotrophic ammoniaoxidizing marine archaeon. Nature 437:543-546

> Levipan HA, Quiñones RA, Urrutia H (2007) A time series of prokaryote secondary production in the oxygen minimum zone of the Humboldt Current System. Prog Oceanogr 75:531-549

Editorial responsibility: Antonio Bode, A Coruña, Spain
Martens-Habbena W, Berube PM, Urakawa H, de la Torre JR, Stahl DA (2009) Ammonia oxidation kinetics determine niche separation of nitrifying Archaea and bacteria. Nature 461:976-979

> Mincer TJ, Church MJ, Taylor LT, Preston C, Karl DM, DeLong EF (2007) Quantitative distribution of presumptive archaeal and bacterial nitrifiers in Monterey Bay and the North Pacific Subtropical Gyre. Environ Microbiol 9: 1162-1175

> Molina V, Farías L (2009) Aerobic ammonium oxidation in the oxycline and oxygen minimum zone of the eastern tropical South Pacific off northern Chile $\left(\sim 20^{\circ} \mathrm{S}\right)$. DeepSea Res II 56:1032-1041

Molina V, Belmar L, Ulloa O (2010) High diversity of ammonia-oxidizing archaea in permanent and seasonal oxygen-deficient waters of the eastern South Pacific. Environ Microbiol 12:2450-2465

Montero P, Daneri G, Cuevas LA, Gonzalez HE, Jacob B, Lizarraga L, Menschel E (2007) Productivity cycles in the coastal upwelling area off Concepción: the importance of diatoms and bacterioplankton in the organic carbon flux. Prog Oceanogr 75:518-530

Mopper K, Kieber DJ (2002) Photochemistry and the cycling of carbon, sulfur, nitrogen and phosphorus. In: Hansell DA, Carlson C (eds) Biogeochemistry of dissolved organic matter. Academic Press, New York, NY, p 455-507

Pérez-Aragón M, Fernandez C, Escribano R (2011) Nitrogen excretion by mesozooplankton in a coastal upwelling area: seasonal trends and implications for biological production. J Exp Mar Biol Ecol 406:116-124

> Raimbault P, Garcia N (2008) Evidence for efficient regenerated production and dinitrogen fixation in nitrogendeficient waters of the South Pacific Ocean: impact on new and export production estimates. Biogeosciences 5: 323-338

Raimbault P, Slawyk G, Boudjellal B, Coatanoan C and others (1999) Carbon and nitrogen uptake and export in the equatorial Pacific at $150^{\circ} \mathrm{W}$ : evidence of an efficient regenerated production cycle. J Geophys Res 104: 3341-3356

Santoro A, Casciotti K, Francis CA (2010) Activity, abundance and diversity of nitrifying archaea and bacteria in the central California Current. Environ Microbiol 12: 1989-2006

Slawyk G, Raimbault P (1995) Simple procedure for simultaneous recovery of dissolved inorganic and organic nitrogen in ${ }^{15} \mathrm{~N}$-tracer experiments and improving the isotopic mass balance. Mar Ecol Prog Ser 124:289-299

Sobarzo M, Djurfeldt L (2004) Coastal upwelling process on a continental shelf limited by submarine canyons, Concepción, central Chile. J Geophys Res 109. doi:10.1029/ 2004JC002350

Varela DE, Harrison PJ (1999) Seasonal variability in nitrogenous nutrition of phytoplankton assemblages in the northeastern subarctic Pacific Ocean. Deep-Sea Res II 46:2505-2538

Ward BB (2008) Nitrification in marine systems In: Capone DG, Bronk DA, Mullholland MR, Carpenter EJ (eds) Nitrogen in the marine environment. Elsevier, Amsterdam, p 199-248

Yool A, Martin A, Fernández C, Clark D (2007) The significance of nitrification for oceanic new production. Nature 447:999-1002

Submitted: March 17, 2011; Accepted: February 17, 2012

Proofs received from author(s): March 30, 2012 